great religious centre and a place of outstanding importance in the Old Empire of the Mayas.

\section{Neanderthal Man in Palestine}

A CABLE received by Miss D. A. E. Garrod, director of the joint expedition of the British School of Archæology in Palestine and the American School of Prehistoric Research, announces a further discovery of skeletons in the Mugharet-es-Sukhul cave by Mr. T. McCown. With those previously discovered, the number of individual skeletons now amounts to seven, presumably the relics of a collective burial. The remains are enclosed in a hard breccia in which are also found a large number of stone implements of Mousterian type.

\section{New Atlantic Flight}

Is 1928, Miss Amelia Earhart (Mrs. Putnam) crossed the Atlantic from west to east in an aeroplane with two others, the late Mr. Wilmer Stultz and Mr. Louis Gordon. On Saturday, May 21, she landed near Londonderry, Northern Ireland, having completed a flight from Harbour Grace, Newfoundland, in about fourteen hours. Miss Earhart is thus the first woman flying alone to cross the Atlantic, and she has also set up a new record for the shortest time for the flight. Her machine was a Lockheed Vega monoplane with a Wasp engine of 420 h.p. Four hours out from Harbour Grace, a leaky joint developed in the exhaust of the engine, causing other parts to work loose and set up vibration. There was also danger from petrol leaking into the cockpit from the petrol gauge. For about five hours during the night, Miss Earhart was flying ' blind ' through bad weather, and during this period her altimeter broke down. In spite of these difficulties, Miss Earhart reached the west coast of Ireland and, being uncertain as to her exact bearings, turned north until she saw the country sloping down to the sea. She landed successfully close to Londonderry.

\section{Lewis Evans Collection at Oxford}

THe Committee of Management of the Lewis Evans Collection of Scientific Instruments has issued its Annual Report. Details are given of the important collection of astronomical, optical, magnetic, and mathematical instruments presented by the Royal Astronomical Society of London. This collection is especially valuable as illustrating the period in the history of astronomical measuring which immediately preceded the time when photographic methods began to be employed for the accurate determination of stellar positions. A very notable addition to the collections illustrating the original association of the Old Ashmolean Museum with the study of natural history in Oxford has resulted from the discovery of a part of the great Lhwyd collection of fossils, which had been lost for two centuries, in a cabinet deposited with the Lewis Evans Collection by Oriel College. These fossils, most of which are in their original wrappings inscribed with data, are of the highest historic interest as being part of the first geological collection in Oxford, and especially as being the original type specimens described and in some cases figured by Lhwyd in his classical work on British palæontology.

\section{Barn Owl Census, 1932}

THE diminishing number of barn (or white) owls in England and Wales in recent years is giving concern to agriculturists and students of bird life. In order to obtain information as to the facts of the case, the Royal Society for the Protection of Birds is instituting a census of barn owls breeding during the summer of 1932 ; and helpers are required in every part of the country to find out and record where in their own localities the birds are nesting. All who may be willing and able to assist the inquiry by undertaking to report upon a definite area, are asked to communicate with Mr. G. B. Blaker, Gaveston Place, Nuthurst, nr. Horsham, Sussex, who is organising the work, and to indicate the extent of the area to be allotted to them. Census forms, with suggestions as to how the work may be carried out most easily and effectively, will then be forwarded. It is hoped that valuable information will thus be obtained as to the status of this useful bird.

\section{Prevention of Cherry Fruit Fly}

WiтH the object of preventing the introduction of the cherry fruit fly into England, the Ministry of Agriculture and Fisheries has issued an order (under the Destructive Insects and Pests Acts, 1877 to 1927) which regulates the importation of cherries during the 1932 season. Cherries grown in France will not be admitted after May 27, except those grown within a small district around Honfleur. Cherries grown in Italy will be admitted until June 5, after which date only those grown in the region of Emilia will be allowed to enter; after June 10, the importation of cherries grown in any part of Italy will be entirely prohibited. Cherries grown in Germany will be admitted until June 26 if accompanied by a certificate of origin; after that date, no German cherries will be admitted except those certified not to have been grown south of lat. $53^{\circ} \mathrm{N}$. or in East Prussia.

\section{Important Collections for Harvard Museum}

Two great collections have recently been added, according to Science Service, to the Museum of Comparative Zoology at Harvard. John Eliot Thayer has presented his series of thirty thousand specimens of bird skins, forming probably the finest private collection of North American birds. The collection also contains many thousands of nests and eggs. Some of the specimens are very valuable: extinct birds include the Labrador duck, the Eskimo curlew, and the passenger pigeon. There are ten eggs of the extinct great auk, and several of the California condor, which is becoming very rare. The second collection, bequeathed by Andrew Gray Weeks, contains some 75,000 specimens of butterflies and moths, many being type specimens. The former owner also left to the museum a fund for the care and increase of the collection.

\section{Researches from the London Hospital}

ANOTHER volume of "Researches", published from the wards and laboratories of the London Hospital 
during 1931, has been issued by the Publications Committee, of which Mr. Hugh Cairns is honorary secretary. It contains $\mathbf{3 3}$ papers, all previously published elsewhere, which range over a wide field in the science and art of medicine. The London Hospital houses a wealth of clinical material, and the staff appears to have made full use of the opportunities for investigation and the publication of adequate records of unusual cases.

\section{Ross Institute}

THE annual report and accounts for 1931 of the Ross Institute and Hospital for Tropical Diseases, Putney Heath, London, S.W.15, shows a serious reduction in contributions in 1931. The Institute at present possesses no endowment fund, and the honorary treasurer, Lord Queenborough, appeals for generous financial support this year. The report also contains a summary of the research work carried out at the Institute, and an account of the results of malaria prevention abroad following measures suggested by the Malaria Department of the Institute.

\section{Announcements}

Prof. C. U. Arikins Kappers will deliver the David Ferrier Lecture at the Royal Society on June 2, taking as his subject "Some Correlations between the Brain and the Skull".

THE annual visitation of the Royal Observatory, Greenwich, will be held on Saturday, June 4, and of the National Physical Laboratory on Tuesday, June 28 .

Dr. E. F. Armstrong (chairman of Council) and Mr. J. Davidson Pratt (general manager) have been appointed representatives of the Association of British Chemical Manufacturers at the Imperial Conference at Ottawa.

A JOINT discussion on "Vision" has been arranged by the Physical and Optical Societies, to be held at the Imperial College of Science and Technology, South Kensington, S.W.7, on Friday, June 3, at 2.30-5.30 P.M. and 7-9.30 P.M. Twenty-eight papers by leading British and foreign contributors have been promised. Visitors will be welcomed; no tickets are required.

IT is announced in Science that Dr. E. C. Franklin, emeritus professor of organic chemistry at Stanford University, has been awarded the Willard Gibbs Medal for 1932 by the Chicago Section of the American Chemical Society for his "work on liquid ammonia solutions, [which] opened up an entirely new field, and also modified profoundly our views on aqueous solutions. He has made a life-long study, characterised by insight, thoroughness and experimental skill, of reactions in liquid ammonia."

The National Baby Week Council announces that 'national baby week' will be held this year on July 1-7. It is suggested that, in view of the present economic crisis, the subject of the economic values of maternity and child welfare work should find a place in local and national propaganda. The report of the Council for 1931 has been issued and gives details of the work accomplished during the year, the competitions organised in connexion with National Baby Week, and awards of the Baby Week challenge shields and prizes.

THE second supplement to the "Bibliography of Bibliographies on Chemistry and Chemical Technology" has been published by the National Research Council of the National Academy of Sciences, Washington, D.C., as Bulletin No. 86. This publication, which completes those previously issued in 1925 (No. 50) and 1929 (No. 71), and noticed in Nature, includes references, classified under subjects, of publications, both books and papers, which contain bibliographies of the subjects. It is a valuable and useful work, which deserves to be widely known, and we are glad to direct attention to the issue of a new supplement.

Applicatrons are invited for the following appointments, on or before the dates mentioned :-A chief veterinary inspector under the Ministry of Agriculture for Northern Ireland-The Secretary, Civil Service Commission, Stormont, Belfast (June 4). An assistant pathologist at the National Hospital, Queen Square-The Secretary, National Hospital, Queen Square, W.C.1 (June 4). A principal of the Cambridgeshire Technical School-The Education Secretary, County Hall, Cambridge (June 6). A lecturer in structural and mechanical engineering at the Constantine Technical College, MiddlesbroughThe Director of Education, Education Offices, Woodlands Road, Middlesbrough (June 6). A Morna Macleod research student in biochemistry at the Lister Institute of Preventive Medicine-. The Secretary, Lister Institute, Chelsea Bridge Road, S.W.I (June 7). A full-time lecturer in mining technology at the Clown Mining and Technical Institute-The Director of Education, County Education Office, St. Mary's Gate, Derby (June 8). A Duddell Scholar of the Institution of Electrical Engineers-The Secretary, Institution of Electrical Engineers, Savoy Place, W.C.2 (June 15). A Rhondda Research Student at Gonville and Caius College, Cambridge (open only to students who are residents or sons of residents in Wales or Monmouthshire)-The Master, Gonville and Caius College, Cambridge. A resident lecturer in biology (including gardening) at the Saffron Walden Training College for Women TeachersThe Principal, Training College for Women Teachers, Saffron Walden, Essex. A Leverhulme fellow for fishery research at University College, Hull-The Registrar, University College, Hull. Part-time lecturers in general biology and physiology, respectively, in the Applied Optics Department of the Northampton Polytechnic Institute-The Registrar, Northampton Polytechnic Institute, St. John Street, E.C.1. A director of the National Institute of Poultry Husbandry, Newport, Shropshire-The Principal, Harper Adams Agricultural College, Newport, Shropshire.

$$
\text { No. 3265, VoL. 129] }
$$

